\title{
FACTORS AFFECTING THE EVENT OF ANEMIA ON STUDENTS
}

\author{
Hartati*, Destriana, Marlina, Muslimin \\ Universitas Sriwijaya, Palembang, Indonesia \\ E-mail: hartati@fkip.unsri.ac.id
}

\begin{abstract}
Anemia is a condition when the body lacks blood cells that contain hemoglobin to spread oxygen to all organs of the body. The impact of anemia for elementary school-age children is that it can cause problems of child growth and development. This study aims to determine the factors that influence anemia in SD Gedung Batin, Negara Inner sub-district, Way Kanan Regency, Lampung Province. This research uses descriptive analytic that is describing and explaining the factors that influence anemia status in 6th grade students at Batin Building, Negara Batin Subdistrict, Way Kanan Regency, Lampung Province. The population in this study were all elementary school students in Batin Building, Batin Negara District, Way Kanan Regency, Lampung Province, totaling 50 students. The sample in this study amounted to 17 students. Research instruments include questionnaires, data collected in the form of primary data and secondary data based on the results of research and data analysis with cross sectional. The analysis shows that the nutritional status based on body mass index BMI there are 5 normal nutrition students, 4 students are fat nutritional status and 8 students are classified as underweight nutritional status. According to normal weight $40 \%$, and low $60 \%$. normal height $53 \%$ and low $47 \%$. The majority are $60 \%$ and $40 \%$ are minority. Parents' income is high as much as $47 \%$ and less $53 \%$. $65 \%$ of junior high / high school education and 35\% of senior high school / elementary / junior high school education. The implication in this research is finding factors that influence anemia, one of which is related to nutritional problems. That the nutritional status based on body mass index of BMI there is 1 student who is very thin, 4 students are thin, 5 students are normal nutrition and 7 students are classified as obese nutritional status according to normal weight $29.41 \%$, and not normal $70.59 \%$ and normal body height $17.64 \%$ and abnormal $82.36 \%$.
\end{abstract}

\section{Keywords: Anemia, Nutritional, Physical Fitness}

\section{Introduction}

Anemia is one of the ten most serious health problems in the world. This health problem is related to the condition of low red blood cell counts or the lack of ability to carry oxygen so that it cannot meet the physiological needs of the organism, Nambiema et.al (2019). Anemia is a condition of hemoglobin ( $\mathrm{Hb})$ levels in the blood less than normal, based on age group, sex and pregnancy, Masrizal (2007). Anemia in children is not only caused by factors of food intake, but can also be caused by infection factors suffered by children, one of which is helminthiasis, Sirajuddin and Masni (2015).

The total world population suffering from anemia is 1.62 billion people with a prevalence of $25.4 \%$ of primary school children worldwide suffering from anemia, WHO (2008). Anemia is a health problem in the global community that affects 305 million school children worldwide. This problem has a bad effect on school children, for example decreased learning achievement, Getaneh et.al

PJKR_

http://jurnal.unimed.ac.id/2012/index.php/jpehr 
(2017). Anemia is a condition where there is a decrease in the number of erythrocyte masses (red cell mass) which is indicated by a decrease in hemoglobin, hematocrit, erythrocyte count (red cell count). Hemoglobin synthesis requires the availability of sufficient iron and protein in the body, proteins play a role in the transport of iron to the bone marrow to form new hemoglobin molecules, Galaher (2008). The anemia level of children is classified into three groups based on the level of hemoglobin in their blood. The mild category ranges from $10-10$ to $10.9 \mathrm{~g} / \mathrm{dl}$, the moderate category ranges from 7.0 to $9.9 \mathrm{~g} / \mathrm{dl}$, and the severe category ranges from less than $7.0 \mathrm{~g} / \mathrm{dl}$, Anokye et.al (2018).

Symptoms of anemia in children have short-term and long-term effects. Anemia damages physical growth and cognitive and motor development, otherwise it can cause social and emotional delays, as well as affect learning activities at school, Xin et.al (2017). The impact of anemia for elementary school children can cause physical growth and development disorders, disease resistance decreases intelligence levels that are less than they should, learning achievement and low sports interest, Sirajuddin and Masni (2015). Anemia that occurs in children if not resolved, it will leave undesirable effects on the ability of students to learn, work, concentrate, mental focus and success in the future, Soleimani (2011).

The causative factors vary by age. Most children suffering from anemia have no symptoms, and this condition can only be detected through screening laboratory tests, Janus and Moerschel (2010). Anemia is generally caused by nutritional problems in the age group of children. It is important to study the characteristics of anemia that occur early in a child's school life, Ahmad et.al (2018). Anemia due to malnutrition occurs due to insufficient nutrition for cells, including the most important nutrient deficiency that can cause anemia deficiency is to iron, folie acid, vitamin B12, vitamin B6, vitamin C, and protein, Soleimani (2011). Inadequate intake of iron-containing foods and consumption of various foods cause anemia, Getaneh et.al (2017).

There are still many Indonesians who have not accustomed breakfast, the same as school-age children at SD Batin Building in Lampung Province, even though not having breakfast will adversely affect the learning process at school, reduce physical activity, and increase the risk of unhealthy snacks. Though the habit of giving children breakfast is one of the main factors for maintaining health and improving children's behavior at school, Permaeseh and Herman (2005). Symptoms of anemia include decreased appetite, abdominal pain after eating, diarrhea, vomiting, coughing pulling worms, worms pulling bigbowel, defecating with blood and itching in the anus. Anemia can reduce the level of physical fitness because hemoglobin in red blood cells functions to channel oxygen into cells for metabolism, Hartati, Destriani, and Victorian (2018). The condition of parents who are not ready to meet the nutritional needs of their children, influenced by lack of financial resources, lack of knowledge about anemia and lack of adequate guidance have an impact on the high health problems of anemia in school-age children, Zuffo et.al (2016). 
Particularly SD Batin Gedung Batin Negara District Way Way District which is a pilot elementary school located in the Lampung area, is a new village where there are still schooling students who have not used shoes, not a few students who are lazy to learn even there are some students who rarely enter school, the majority of the inhabitants of this village are middle to lower class residents, this can be seen from the suitability of children's school uniforms, daily life, inadequate road access.

Based on the facts, it is necessary to do research on anemia factors that can reduce learning achievement and physical fitness of elementary school students Batin Building, Batin Negara District, Way Kanan Regency, Lampung Province.

\section{Method}

The type of data used in this study is secondary data from a survey conducted in the Batin Building Elementary School, Negara Batin District, Way Kanan Regency and the data can be seen in the appendix. The research design that will be used is through a quantitative approach to the cross sectional research design. Cross sectional is a study to study the correlation between risk factors by approaching, observing, or collecting data at one time (point time approach). That is, each research subject only observed once and measurements were made of the character status or subject variables at the time of examination. This type of research uses descriptive analytic that is describing and explaining the factors that influence anemia status in 6th grade students at SD Batin Gedung Negara Batin District Way Kanan Regency Lampung Province.

The population in this study were all elementary school students in Batin Building, Batin Negara District, Way Kanan Regency, Lampung Province, totaling 50 students. The sample in this study consisted of grade VI students. The age of the respondents varied from 10 to 14 years 10 -year-old students totaling 3 students, 11 years, totaling 4 students, 12 years totaling 4 students, 13 students totaling 4 students, 14 years totaling 2 students. This dependent variable is the nutritional status of 6th grade students in Batin Building, Batin Negara District, Way Kanan Regency, Lampung Province. The independent variable is nutritional status, weight, height, age, parental education and parental occupation. Research instruments include questionnaires, data collected in the form of primary data and secondary data, the instrument used in this study was a questionnaire

\section{Discussion}

The study was conducted at SD Batin Gedung Way Kanan Regency, Lampung on 18 February - 19 February 2019.

Table 1. Distribution of Characteristics of Batin Building Elementary Students

\begin{tabular}{|c|c|c|}
\hline Variabel & Amount & Percentage $(\%)$ \\
\hline \multicolumn{3}{|l|}{ Age } \\
\hline $10-12$ years & 7 & $40 \%$ \\
\hline 13-14 years old & 10 & $60 \%$ \\
\hline
\end{tabular}

PJKR_

http://jurnal.unimed.ac.id/2012/index.php/jpehr 


\begin{tabular}{lcc} 
Weight & & \\
Normal body weight & 5 & $29,41 \%$ \\
Abnormal Weight & 12 & $70,59 \%$ \\
\hline Height & & \\
Ideal height & 3 & $17,64 \%$ \\
Height Not Ideal & 14 & $82,36 \%$ \\
\hline
\end{tabular}

Table 1 . shows that of the 17 students who were $10-12$ years old (40\%), the majority were 13-14 years old (60\%). it is known that the frequency obtained from the results shows that of the 17 students most had normal weight of $29.41 \%$, while those who had abnormal body weight were $70.59 \%$. Based on the data obtained shows that students have an ideal height of $17.64 \%$, while those who are not ideal height are $82.36 \%$.

The results of the study showed that of 17 students, 1 student was declared very thin, 4 students were categorized as thin, 5 students were categorized as normal and 7 students were categorized as fat, which can be seen in Table 2.

Table 2. Distribution of Nutrition Status Based on BMI

\begin{tabular}{clcc}
\hline No & Nutrition Status & Amount & Percentage(\%) \\
\hline 1 & Very thin & 1 & $6 \%$ \\
2 & Thin & 4 & $25 \%$ \\
3 & Normal & 5 & $28 \%$ \\
4 & Fat & 7 & $41 \%$ \\
\hline
\end{tabular}

Based on the analysis of the relationship between parental income and the incidence of anemia, it was found that anemia cases occurred in students with low parental income by 9 respondents (53\%) and in students with high parental income by 8 respondents $(47 \%)$. Parental education, which includes tertiary education, is $\geq 9$ years old or graduated from high school or graduated from tertiary education, while parental education who assist in low education is $\leq 9$ years old or graduated from elementary or junior high school. Based on the results of the study, the frequency of parental education is as high as $(65 \%)$ than the frequency of parental education as much as (35\%). The complete information can be seen in Table 3. below:

Table 3. Relationships of Parental Income, Parental Education, and Anemia

\begin{tabular}{lcc}
\hline \multirow{2}{*}{ Anemia } & \multicolumn{2}{c}{ Total } \\
\cline { 2 - 3 } & Amount & Percentage(\%) \\
\hline Low Parent Income & 9 & $53 \%$ \\
High Parent Income & 8 & $47 \%$ \\
total & 17 & $100 \%$ \\
\hline Higher Education for Parents & 11 & $65 \%$ \\
Low Parent Education & 6 & $35 \%$
\end{tabular}

PJKR

http://jurnal.unimed.ac.id/2012/index.php/jpehr 
Teenagers are individuals aged 10-19 years who are divided into two terminations, namely early adolescents at the age range of 10-14 years and late teens 15-19 years. Adolescence is a transition from childhood to adulthood which experiences all development of all aspects or functions to enter adulthood, Argana (2004). The nutritional status of a person can be known through the assessment of food consumption based on qualitative and quantitative data such as Body Mass Index (BMI) and Hb levels, Asih and Pratiwi (2010).

Several studies report that nutritional deficiencies will reduce the capacity of the immune system to respond to pneumonia infection including impaired granulocyte function, decreased complement function, and also cause micronutrient deficiencies, Hartati (2012).

Supplements of iron or iron in foods with added micronutrients will have an beneficial effect on the status of hemoglobin $(\mathrm{Hb})$ in children who are at risk of micronutrient deficiency, Rosado et.al (2010). Suplemetation of iron tablets is considered an effective way because the iron content is solid and is equipped with folic acid which can simultaneously prevent and treat anemial due to folic acid deficiency, Roossleyn (2016). Good nutritional status can improve high physical fitness, Sukendro and Zulfa (2018). Strategies and extension programs about the importance of paying attention to nutritional intake of food in children will indirectly prevent anemia, Zuffo et.al (2016).

Physical changes due to growth that occur will affect the health status and nutrition. An imbalance between intake of needs or adequacy will lead to nutritional problems, both in the form of over nutrition and under nutrition, Masthalina (2015). Nutritional problems commonly found in adolescents include anemia, obesity, chronic lack of energy or KEK, then deviant behavior such as anorexia nervosa and $_{\text {sim }}$ bulimia. This study found that the frequency of 17 elementary school students in Batin Building, aged 10-12 years, was 40\%, while those aged $13-15$ were $60 \%$. this shows that in this school many students are aged from 13-15 years.

Based on the analysis of elementary school students Batin Building shows that of the 17 students who have normal weight as much as $29.42 \%$, while students who have abnormal weight as much as $70.59 \%$. Body composition can be known by BMI or measurement of Body Mass Index, Amir (2015).

In this study, Batin Gedung elementary school students obtained data that from 17 students, some students had an ideal height of $17.64 \%$, while students who had an ideal height were $82.36 \%$. Worm infections will cause various health problems such as itching, loss of appetite, anemia, or blockage of the digestive tract that requires operative measures, Hartati, Aryanti, Muherman (2017).

Anthropometric measurements can be used to identify a person's nutritional status, Bhattacharya (2019). Anthropometric test by measuring body weight (body weight) and height (TB) using Body Mass Index or BMI, Hartati, Yusfi, Destriani (2017). BMI is the result of the distribution of BW in $\mathrm{kg}$ by the 
square of $\mathrm{TB}$ in $\mathrm{m} 2$ (BB / TB2). The frequency obtained from the results of the study showed that of 17 students, 1 student was declared very thin, 4 students were categorized as thin, 5 students were categorized as normal and 7 students were categorized as obese. Based on the statements of the experts above stated that the results of this study allow the number of students who are obese because half of the students sampled have normal nutritional status.

In this study, data were obtained that parents' income in Batin Gedung SD parents had a high monthly income (income> Rp. 500,000) and low parental income (income $<\mathrm{Rp} .500,000$ ), based on the results of research on high parental income frequency of $47 \%$ while the frequency of income of parents who are more or less as much as 53\%. In this study the parents' income of Batin Gedung Elementary School Students was classified into 3 namely; higher education (education $>9$ years or graduated from high school and or graduated from college) and low parental education (education $\leq 9$ years or graduating from elementary school and / or graduating from junior high school). Based on the results of the study, the frequency of parental education is high $(65 \%)$ than the frequency of parental education is lacking (35\%).

\section{Conclusion}

Based on the results of the research that has been done, it can be concluded that the nutritional status based on body mass index of BMI there is 1 student who is very thin, 4 students are thin, 5 students are normal nutrition and 7 students are classified as obese nutritional status according to normal weight $29.41 \%$, and not normal $70.59 \%$ and normal body height $17.64 \%$ and abnormal $82.36 \%$.

The prevalence of iron deficiency anemia in elementary school students in Gedung Batin class VI is known that the percentage of anemia events in this study belongs to the category of health problems and intervention needs to be taken to deal with these problems and respondents who have low-income parents more than high-income parents, as many as $47 \%$ and less $53 \%$ of respondents who have less educated parents more than highly educated parents are determinants of anemia.

\section{References}

Ahmad, M. S., Farooq, H., Maham, S. N., Qayyum, Z., Waheed, A., \& Nasir, W, 2018. Frequency of Anemia and Iron Deficiency Among Children Starting First Year of School Life and Their Association With Weight And Height. Anemia. 1-5.

Amir, N, 2015. Hubungan motor educability, Indeks Massa Tubuh dan motivasi belajar dengan prestasi belajar Penjasorkes. ALTIUS Jurnal Olahraga dan Kesehatan. Volume: 1, Edisi: 1: -

Anokye, R., Acheampong, E., Edusei, A. K., Mprah, W. K., Ofori-Amoah, J., Amoah, V. M. K., \& Arkorful, V. E, 2018. Perception of Childhood Anaemia Among Mothers in Kumasi: A Quantitative Approach. Italian Journal of Pediatrics. Volume: 44, Edisi: 1: 1-6. 
Argana, G, 2004. Vitamin C Sebagai Dominan Untuk Kadar Hemoglobin Pada Wanita Usia 20 Sampai 35 Tahun. Jurnal kedokteran Trisakti. Volume: 23, Edisi: 1: -

Asih dan Pratiwi, 2010. Prilaku Prososial Ditinjau Dari Empati Dan Kematangan Emosi. Jurnal Psikologi Universitas Muria Kudus. Volume: 1, Edisi: 1: -

Bhattacharya, A., Pal, B., Mukherjee, S., \& Roy, S. K, 2019. Assessment of Nutritional Status Using Anthropometric Variables by Multivariate Analysis. BMC Public Health. Volume: 19, Edisi: 1: 1-9.

Galaher, M.L, 2008. The Nutrients and Their Metabolism. in: Mahan LK, Escottstump S. M krause's Food, Nutrition, and Diet Therapy. 12 th edition. Philadelphia: Saundres.

Getaneh, Z., Enawgaw, B., Engidaye, G., Seyoum, M., Berhane, M., Abebe, Z., \& Melku, M, 2017. Prevalence of Anemia and Associated Factors Among School Children in Gondar Town Public Primary Schools, Northwest Ethiopia: A School-Based Cross-Sectional Study. Plos One. Volume: 12, Edisi: 12: 1-13.

Hartati, Aryanti, S., Muherman, S.Y, 2017. Anthelmintic Intake onthe Nutritional Status, Hemoglobin Content, and Learning Achievement ofthe Elementary School Student in Sukarami Palembang. 1st Annual Applied Science and Engineering Conference, IOP Conf. Series: Materials Science and Engineering 180, FKIP Unsri. Palembang: Universitas Sriwijaya.

Hartati, Destriani dan Victoria, A.R, 2018. Worm Disease Profile of Primary School Children. The Consortium of Asia-Pacific Education Universities (CAPEU), IOP Conf. Series: Materials Science and Engineering 296, FKIP Unsri. Palembang: Universitas Sriwijaya.

Hartati, S, 2012. Faktor risiko terjadinya pneumonia pada anak balita, Jurnal Keperawatan Indonesia. Volume: 15, Edisi: 1: -.

Hartati, Yusfi, H., dan Destriani, 2017. Designing The Scientific Characteristics of Learning Model to Improve The Mastery of Concept on Nutrition Science II of Prospective Teachers of Physical and Health Enducation, Advances in Social Science. Enducation and Humanities Researc Atlantis Press, FKIP Unsri. Palembang: Universitas Sriwijaya.

Janus, J., \& Moerschel, S. K, 2010. Evaluation of Anemia in Children. American Family Physician. Volume: 81, Edisi: 12: 1462-1471.

Masrizal, 2007. Anemia Definisi Besi. Jurnal Kesehatan Masyarakat. Volume: 2, Edisi: 1: -

Masthalina, H, 2015. Pola konsumsi (Faktor Inhibitor dan Enhancer Fe) Terhadap Status Anemia Remaja Putri. Nusa Tengara Barat: Jurusan Gizi Poltekkes Kemenkes Mataram.

Nambiema, A., Robert, A., \& Yaya, I, 2019. Prevalence and Risk Factors of Anemia in Children Aged From 6 To 59 Months In Togo: Analysis From Togo Demographic And Health Survey Data, 2013-2014. BMC public health. Volume: 19, Edisi: 1: 1-9.

Permaeseh, Herman S, 2005. Faktor-faktor yang Mempengaruhi Anemia pada 
Remaja. Jurnal Buletin Penelitian Kesehatan. Volume: 4, Edisi: 1: -.

Roossleyn I., P., T, 2016. Strategi Dalam Penanggulangan Pencegahan Anemia Pada Kehamilan. Jurnal Ilmiah Widya. Volume: 3, Edisi: 3: -.

Rosado, J. L., Gonzalez, K. E., Del C Caamaño, M., García, O. P., Preciado, R., \& Odio, M, 2010. Efficacy of Different Strategies to Treat Anemia in Children: A Randomized Clinical Trial. Nutrition Journal. Volume: 9, Edisi: 1: 1-10.

Sirajuddin, S., dan Masni, 2015. Kejadian Anemia Pada Siswa Sekolah Dasar. Jurnal Kesehatan Masyarakat Nasional. Volume: 9, Edisi: 3: -.

Soleimani, N, 2011. Relationship Between Anaemia, Caused From The Iron Deficiency, And Academic Achievement Among Third Grade High School Female Students. Procedia-Social and Behavioral Sciences 29: 1877-1884.

Sukendro dan Zulfa, I, 2018. Hubungan Status Gizi Terhadap Kebugaran Jasmani Pada Siswa Sekolah Menengah Atas Negeri 10 Merangin. Jurnal Physical Enducation, Health and Recreation. Volume: 2, Edisi: 2: -.

WHO, 2008. Wordwide Prevalance of Anemia 2005. Who Global Data Base On Anemia. Geneva: WHO library cata loguing-in-publication data.

Xin, Q. Q., Chen, B. W., Yin, D. L., Xiao, F., Li, R. L., Yin, T., \& Wang, L. H, 2017. Prevalence of Anemia and Its Risk Factors Among Children Under 36 Months Old in China. Journal of Tropical Pediatrics. Volume: 63, Edisi: 1: 36-42.

Zuffo, C. R. K., Osorio, M. M., Taconeli, C. A., Schmidt, S. T., Da Silva, B. H. C., \& Almeida, C. C. B, 2016. Prevalence and Risk Factors of Anemia in Children. Jornal De Pediatria (Versao Em Portugues). Volume: 92, Edisi: 4: 353-360.

\section{Journal Physical Education, Health and Recreation}

pubisets

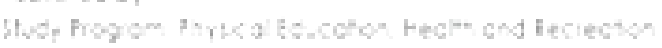

